\title{
The "New Doctorate" in Austria: Progress toward a Professional Model or Status Quo?
}

Hans Pechar, ${ }^{* 1}$ GÜlay Ates ${ }^{2}$ And Lesley Andres ${ }^{3}$

$\sim \quad$ Until recently, both policy direction and public awareness of the Bologna Process has been focused almost unilaterally on the introduction of the Bachelor's degree to European universities. This is understandable, as for most European countries, the Bachelor is a new academic degree. However, commencing with the Berlin Ministerial Conference (Realising the European Higher Education Area, 2003), reform of doctoral studies has been highlighted as a second equal pillar in the Bologna reform process. In this paper, we begin by providing an overview of the general policy background and the rationales that underlie the attempts to restructure doctoral studies in Europe. Next, we focus on the specific situation in Austria, where peculiarities of the status quo collide with uniquely Austrian approaches to reforming doctoral education. Finally, through two case studies, we examine initial attempts - and related challenges - to implement the "New Doctorate" in Austria.

Keywords: Bologna reform, doctoral studies, professional model, apprenticeship model, Austria

$1{ }^{\star}$ Corresponding author. Faculty of Interdisciplinary Studies (IFF), Vienna Location, Institute of Science Communication \& Higher Education Research, University of Klagenfurt, Austria Hans.Pechar@uni-klu.ac.at

2 Faculty of Interdisciplinary Studies (IFF), Vienna Location, Institute of Science Communication \& Higher Education Research, University of Klagenfurt, Austria Guelay.Ates@uni-klu.ac.at

3 Department of Educational Studies, University of British Columbia, Canada lesley.andres@ubc.ca 


\section{»Novi doktorat« v Avstriji: razvoj v smeri profesionalnega modela ali status quo?}

Hans Pechar, * Gülay Ates in Lesley Andres

$\propto$ Do pred kratkim so bili politične usmeritve bolonjskega procesa in seznanjanje javnosti o njem skoraj enoznačno osredinjeni na vpeljavo prve stopnje študija (Bachelor) na evropske univerze. To je razumljivo, ker je za večino evropskih držav to nova akademska stopnja. Toda reforma doktorskega študija je bila, začenši z ministrsko konferenco v Berlinu (Realising the European Higher Education Area, 2003), predstavljena kot drugi enakovreden steber v procesu bolonjskih reform. Na začetku članka podajamo pregled splošnega ozadja politik in razlogov, ki podpirajo poskuse rekonstruiranja doktorskega študija v Evropi. Nato se osredinimo na specifičen položaj v Avstriji, kjer svojskosti statusa quo trčijo z unikatnim avstrijskim pristopom k reformiranju doktorskega izobraževanja. $\mathrm{Na}$ koncu s pomočjo dveh študij primerov analiziramo začetne poizkuse in $\mathrm{s}$ tem povezane izzive implementacije »novega doktorata « v Avstriji.

Ključne besede: bolonjska reforma, doktorski študij, profesionalni model, pripravniški model, Avstrija 


\section{Professional and Apprenticeship Models of Doctoral Studies}

Most controversies surrounding the Bologna Process dwell on the introduction of the Bachelor's degree. In the Germanic countries, this new degree is widely regarded as a departure from the Humboldtian tradition, that emphasises cultivation of the mind as the main mission of higher education. By contrast, the Bachelor's degree within the Bologna framework places much more emphasis on employability, which is often regarded as a sellout of higher education to the interests of the business sector and a further step towards the "Americanisation" of European universities (for a critique of this perspective, see Pechar, 2012).

Controversies surrounding the introduction and implementation of the Bachelor's degree have managed to outshine the reform efforts in doctoral education that were introduced at the Berlin Conference of Ministers meeting in 2003. Within the Bologna framework, doctoral education is regarded as the "third study cycle" and as the link between the European Higher Education Area and the European Research Area (European Ministers Responsible for Higher Education, 2005). When compared to Bachelor's degree reforms, such efforts directed at the European doctorate are much more influenced by the American model of the $\mathrm{PhD}$. The introduction of the Bachelor's degree can be interpreted as an adoption of the Anglophone two tier architecture, that distinguishes between undergraduate and postgraduate education. However, the Bachelor's degree, as specified in the Bologna architecture, is fashioned after the British, and not the American model. In the majority of the countries that have implemented the Bologna Process, the Bachelor's degree is three years in length and is specialised (the British model), rather than four years with a considerable amount of non-specialised, liberal education (the American model).

In contrast, reform of doctoral education in Europe has strongly embraced the American model of the $\mathrm{PhD}$. Frequently in comparative higher education research, two models of doctoral education are juxtaposed (Rhoades, 1991). On the one hand, the apprenticeship model has as its core a strong personal relationship between the master and his or her disciple. This model is characterised by a low degree of standardisation and formalisation, which allows for a high degree of personal discretion by the master. On the other hand, in the professional model, ${ }^{4}$ the individual mentor is one component within the collective

4 The term "professional model" refers to the theoretical differentiation of two modes of doctoral training as distinguished by Gumport (1992) and Rhoades (1991), and should be confused neither with postgraduate education provided by professional schools nor with a "professional doctorate". 
responsibility of the department and the institution. As such, a higher degree of formalisation and standardisation reduces the personal discretion of the individual supervisor. These two models have geographical coordinates. Whereas the professional model is an ideal type description of doctoral education in the USA, the apprenticeship model, for the most part, describes traditional forms of doctoral education in Europe. In this paper, we are unable to describe in any detail the diverse forms of apprenticeship and profession models across various jurisdictions. In the following section, we focus on a comparison of American and traditional Germanic models of doctoral education. ${ }^{5}$

The apprenticeship model has its origins in the medieval university. It was modernised in the early 1800 s by the introduction of the chair structure of the Humboldtian university. When compared to earlier forms of higher education, neo-humanist reforms resulted in a completely new approach to doctoral training. Before Willhelm von Humboldt legitimised the research mission of universities, the doctoral dissertation was simply a confirmation of the authoritative knowledge transmitted in early modern universities. Remarkably, it was primarily the professor, and not the student, who wrote the doctoral dissertation. The task of the student was to defend the dissertation of his master; it was neither expected nor desired that the student produce any original knowledge on his own. To develop one's own dissertation would have been regarded as a presumptuous provocation of the established order of knowledge. When the new model of doctoral training introduced the requirement of original research by the student, traditional professors complained that it led to a "decline in quality" (Rasche, 2007a, p. 198).

The establishment of a rigorous new research doctorate across Germany occurred over an extended period of time. In its place lingered less demanding forms of doctoral examinations, such as the doctorate in absentia (i.e., not present) that coexisted with doctoral dissertations based on original research. As late as 1876 , Theodor Mommsen, a renowned historian at the University of Berlin, attacked the former as German diploma mills that produced "pseudodoctors" (Rasche, 2007b). For such graduates, the Doctoral degree signalled readiness to enter the labour market rather than as a step toward an academic career. Moreover, the general standards for doctoral training were significantly lower than today. For example, preparation and completion of a dissertation was usually completed in few months and rarely took more than a year (Paletschek, 1998). Relaxed standards at the doctoral level could not seriously

5 It is noteworthy that the Germanic model has strongly shaped doctoral education in many European countries, predominantly in Northern and Eastern Europe. Likewise, the American model has shaped doctoral programmes in Anglo-Saxon countries. Since the 1980s, it has served as a model for doctoral reform in Europe. 
damage the academic quality of the system because the gatekeeper to the academic profession was no longer the Doctoral degree, but the Habilitation (an additional professorial dissertation).

The Humboldtian concept of the university emphasised "unity of research and scholarship", which embedded specialised research within a common neo-humanist framework; hence, specialisation at the German research university of the early 19 th century was weak. Although specialisation increased during the later decades of the century, the chair structure served as a centre of gravity around which all academic activities were concentrated. Because he possessed a high degree of autonomy in academic affairs, the Professor Ordinarius was granted full control and responsibility for research and teaching activities in his discipline, including doctoral training. This was the historical context from which the apprenticeship model emerged.

The professional model arose out of a very different set of historical circumstances. American higher education gained status and social support relatively late, when industrialisation after the civil war led to rapidly increasing demands for professional qualifications. During that period, many academics who were familiar with the German system established research universities and transferred some elements of the Humboldtian model to their home institutions. Attempts to establish pure doctoral institutions were not successful. As Gade (1991) explains,

rather than developing separate institutions for research and advanced instruction, these functions were grafted onto existing institutions, turning many colleges into universities and creating another distinctive American form, the comprehensive institution, containing undergraduate education on the British model, and research and graduate work on the German model. (p. 1082)

Furthermore, the organisational home for doctoral education in the US was not the chair structure but the department, which had major consequences in terms of the structure of doctoral education. In contrast to a system organised around faculties and chairs, rooted within a guild structure and a tradition of the "private discretion and prerogatives of individual faculty" (Rhoades, 1991, p. 132), a department within the college system was more public, formalised, transparent, and focused on specialisation and scholarship. Instead of the German tradition of a "pre-professional guild pattern of particularistic, informal apprenticeship" (p. 132), American doctoral education was organised around the principles of formal professional education and certification. 
The recent reform debate in Europe is strongly oriented around the key features of the professional model of doctoral education. The following points are at the centre of this discussion:

(1) What is the role of the institution as opposed to the individual supervisor in doctoral training? In the traditional European model, it is the professor who has full control and responsibility for all phases - from admission to graduation - of doctoral study. More recently, however, many European universities have introduced doctoral schools that try to be equivalents of American graduate schools, with the goal of strengthening institutional responsibility for doctoral education.

(2) Should responsibility for supervision rest on one individual academic or on a supervisory team? The individual supervisor is predominant in the traditional European model. More recently, this heritage of the chair structure has come under question, and collegial supervision by a team is preferred.

(3) Is access to doctoral education regulated by clear and unambiguous admission procedures at the institutional level, or is it driven by informal decisions of individual professors or supervisors? The professional model is characterised by transparent admission procedures, whereas in the apprenticeship model, entitlement (to enrol "in principle") is combined with opaque routes to secure a supervisor. The idiosyncratic "no admission" policy in Austrian higher education (Pechar, 2009) constitutes a particular challenge for this area of reform.

(4) To what extent does doctoral training require a structure and additional coursework? The traditional European pattern rested on the assumption that doctoral students have already acquired a sufficient methodological basis for undertaking research in their respective subject. Hence, the doctoral student can proceed with a dissertation without additional coursework. More recently, however, structured and semi-structured doctoral programmes have been introduced that require additional coursework, mainly in advanced research techniques.

(5) Who evaluates the dissertation? Is this the responsibility of the supervisor or of an external examination team? Traditionally in the German speaking world, assessment was the responsibility of the individual supervisor. More recently, the functions of supervision and evaluation have been increasingly separated and different levels of external assessment have been implemented. Assessment can be external to the supervisory team, external to the institution, and external to the national academic culture.

In the next section, we focus our attention on doctoral programmes in Austria. 


\section{Doctoral Education in Austria}

A fundamental reform of its universities began in Austria after the revolution of 1848 and continued into the liberal era in the 1870 , when the Humboldtian vision of Wissenschaftsfreiheit - that is, freedom of teaching and research, unrestricted by religious or political intervention - was fully established (Ferz, 200o). Together with the chair structure and the habilitation system, Austria adopted the apprenticeship model of doctoral training that required a German-style dissertation (Clark, 2006).

Until the 1960s, the Doctoral degree was the first academic degree at Austrian universities. ${ }^{6}$ Following a major study reform process in 1966, a Diploma degree (equivalent to the Anglophone Master's degree) was introduced in order to distinguish between non-doctoral and doctoral study. The policy intention was to specify the Doctoral degree as the trajectory towards a research career, while providing students who wanted to enter the labour market an exit option at a lower academic level (Götz, 1993). In practice, however, the differentiation between the Diploma and the Doctoral degree remained weak. Doctoral education did not provide research training comparable to the American $\mathrm{PhD}$, and many students continued to use the Doctoral degree as a signal to enter the professional labour market.

Expansion of higher education since the 1960 s has been shaped by the conditions of conservative welfare regimes (Esping-Andersen, 1990), that are not conducive to high participation rates (Pechar \& Andres, 2011). Austria is among the OECD countries with the lowest proportion of its 25-34 year-old population having attained tertiary credentials (ISCED 5) (21\% as opposed to the OECD average of 37\%). Moreover, the difference between the 25-34 year age cohort (21\%) and the 55-64 year age cohort $(16 \%)$ is among the smallest of all OECD countries. In other words, Austria ranks at the bottom end and has not significantly improved during the last 30 years (OECD, 2011, p. 40).

The low tertiary participation rate can be explained partly by the characteristics of Austrian secondary schools. Austria is among the very few countries that still practice early streaming at age 10. Immediately after only four years of elementary school, pupils are streamed into either preparatory schools for higher education (Gymnasium) or "main schools" (Hauptschule). The latter are

6 However, as in Germany, graduates who wanted to enter a career in the civil service, in the liberal professions (law, medicine), or as a teacher had to pass a state exam in the Gymnasium. This kind of "ex post control" by the government made the high degree of freedom in teaching and learning possible (Anderson, 2004).

7 Due to generous interim arrangements, some first degree doctorates were awarded until the 1990 . 
designed for students who allegedly are not academically inclined, but instead possess "handicraft talent." This pattern of early streaming limits both the ambition of students and the pool of those who are eligible for higher education. It is telling that only $24 \%$ of Austrian students at age 15 expect that they will attend tertiary education after completing secondary school, compared to the OECD average of $41 \%$ (OECD, 2007). ${ }^{8}$

Given the low tertiary graduation rate at ISCED 5 , it is interesting that the rate of Doctoral degrees (ISCED 6) in Austria (2.0\%) is higher than the OECD average of 1.5\% (OECD, 2011). Again, this seeming paradox can be explained by the educational characteristics of conservative welfare regimes, that still feature many characteristics of sponsored mobility. According to Turner (1960), early selection of the future elite, encouraged by the sponsored mobility norm, goes hand in hand with reduced competitive pressure for the elite cohort once they are selected. This theory provides a solid explanation of transitions in the Austrian education system. After being assigned elite status at age 10, students who complete the Gymnasium are entitled to enrol in any study subject at any university without further selection and admission procedure (Pechar, 2009). This kind of entitlement system was a familiar pattern in European countries in the era of elite higher education. As a consequence of educational expansion, most countries have either abolished or modified their entitlement rules in order to accommodate the realities of mass higher education. Austria, however, has maintained the entitlement system and does not allow universities to select and admit students. Moreover, this rule applies not only to the transition from secondary schools to universities, but also to gaining access to postgraduate education - that is, master's and even doctoral studies. According to this logic, any successful completion of a prior step of study is accompanied by entitlement to enrol in the next advanced step.

The odd pattern of low graduation rates at ISCED 5 and high graduation rates at ISCED 6 was long regarded as a special virtue of the Austrian higher education system. As the saying goes, "we educate only few at the tertiary level, but those particularly well." More recently, however, leading academics and policy makers have recognised the inadequacies of this traditional pattern. Despite high rates of awarding Doctoral degrees, the share of researchers in the Austrian labour force is relatively low, to the extent that research-intensive

8 Another explanation for the low participation and graduation rate the tertiary level is the well developed system of vocational education and training at the upper secondary level. Vocational training, both in dual and school-based forms, is regarded as one of the strengths of the Austrian education system. It is controversial whether this system still satisfies the qualification demands of an increasingly knowledge-based economy, but it is undeniable that the secondary VET sector fulfils many functions that in other countries are performed at the tertiary level (Graf, Lassnigg, \& Powell, 2012). 
industries complain about a lack of trained research personnel. ${ }^{9}$

Pressure at the European level and dissatisfaction within national constituencies have resulted in attempts to restructure doctoral education. A key document at the European level has been one entitled Salzburg Principles, that emerged from a "Bologna seminar" aimed to identifying the key challenges of linking the European higher education area and the European research area. Seminar participants agreed upon ten basic principles "that should underpin further considerations of the key role of doctoral programmes and research training in the Bologna Process" (European University Association, 2005). This document emphasises that "universities as institutions need to assume responsibility" for the quality of doctoral education (Principle 2), and it highlights the "crucial role of supervision and assessment" (Principle 5). On the bases of the Salzburg Principles, the Austrian Rectors' Conference (now Universities Austria) adopted the Recommendations on New-Style Doctoral Studies in 2007. This document emphasises the importance of supervision and guidance, and recommends that "the formerly bilateral relationship between supervisor and doctoral candidate (individual supervision) should be broadened to integrate the candidate into a team, for example as part of a doctoral programme" (Universities Austria, 2007, p. 36). With respect to admission, the document states that "unrestricted entry to doctoral studies, as is currently the case in Austria, entails that prospective doctoral candidates are not selected on the basis of qualifications and university capacities" (p. 37). Regarding the assessment and examination of doctoral candidates, the recommendations advocate that "at least one examiner should come from a field that is not too close to that of the supervisor (and should ideally be from abroad)" (ibid., p. 40).

This reform debate coincided with a major governance reform that introduced the new public management model to the world of higher education (Pechar, 2005). The legal foundation for the new governance regime is the University Act 2002 (UG, 2002). During the preparation of this new act, far-reaching proposals to abolish the Habilitation and substitute it with substantially upgraded doctoral training were discussed (Novak, 2006).

In the end, however, a more cautious path of reform was chosen. The Habilitation was maintained, ${ }^{10}$ and at the same time the quality standards of doctoral training were raised. Two measures were undertaken in order to raise the quality of doctoral training. First, the minimum duration of doctoral training was increased by one year, from two to three years. Second, new forms

9 "In human resources, the indicators point towards the relatively low proportion of academically trained people. ... Interestingly, and in contrast to this position, the number of new doctorates is significantly higher than the EU 27 average" (Schibany et al., 2011).

10 It is possible, however, that the Habilitation will become dispensable once the qualitative upgrading of doctoral training takes full effect. 
of doctoral programmes have been established. Individual modes of doctoral study, which dominated until recently, have now for the most part been substituted by new models of semi-structured or structured programmes. The Austrian doctoral reform is termed as Doktorat Neu. Since the winter semester $2009 / 2010$, doctoral students have only been able to enrol under the new terms and conditions of Doktorat Neu.

As we demonstrate in the next section, the new model of doctoral studies does not constitute a radical break with the past. The Austrian University Act of 2002 (UG, 2002) provides the legislative framework for recent changes to doctoral programmes. Because the Austrian "no admission policy" has remained in place, strong continuity with the past has been retained;" that is, every student who completes the preceding level of study is entitled to enrol in the ensuing level of education. ${ }^{12}$ However, compared to the former system, some substantive changes have taken place. Most of these changes, such as the composition of curricula, admission procedures, assessment of the dissertation, and supervision, are regulated at the university level, the disciplinary level, or both.

In keeping with the European Credit Transfer System, in 2004 the UG 2002 established the requirement of 180 ECTS points for a Doctoral degree and 240 ECTS for a PhD degree. This legislative paragraph 54(4) was amended in 2006. Since that time, the number of ECTS points has no longer been specified by law or regulation; only the length of doctoral study is specified at three years. Despite this legislative change, some universities continue to retain ECTS points. When compared with the former system, different policies for retaining students in doctoral studies have been adopted; however, these procedures are not necessarily consistent across universities, or even across disciplines within universities. Regarding the tasks of doctoral students, doctoral agreement contracts and annual progress reports have been established. In the past, the main supervisor was responsible for overseeing, evaluating and assigning grades for doctoral projects, with the second evaluator being relegated to a minor role.

In the following section, we describe the ways in which the Doktorat $\mathrm{Neu}$ at the Faculty of Social Sciences at the University of Vienna and the Department of Social Sciences and Economics at the University of Graz ${ }^{13}$ were

11 "Enrolment" in Austria simply entails signing up for a programme and paying student union fees.

12 The Act UG 2002, \$64(4) stipulates that a master's degree entitles a student to enrol in a doctoral programme of a corresponding subject.

13 At the University of Vienna, the Faculty of Social Sciences is comprised of the Departments of Journalism and Communication Sciences, Nursing Science, Political Science, Social and Cultural Anthropology, Sociology and Social Studies of Science. At the University of Graz, the Department of Social Sciences and Economics includes the following: Business Education and Development, Business Studies, and Economics and Sociology. 
implemented. We do so by addressing the following questions: What kinds of admission procedures have been established? Are there any differences between universities even when we limit our analyses to one discipline? What changes can be observed at the curricular level? How structured is the Doktorat Neu study within each faculty? What is the initial impact of these changes on enrolment numbers, recruitment, supervision and assessment of doctoral theses?

\section{Case Studies of the University of Vienna and the University of Graz}

In the winter semester ${ }^{14}$ 2011, almost 29,000 doctoral students were enrolled in Austrian universities. Of these newly designated "early stage researchers", as they are described by the Bergen Communiqué (2005, p. 4), ${ }^{15} 35 \%$ were enrolled at the University of Vienna and $9 \%$ were enrolled at the University of Graz. ${ }^{16}$ In 2011, 22\% of all doctoral candidates in the field of social (and economic) sciences were enrolled at the University of Vienna, $26 \%$ at the Vienna University of Economics and Business, $17 \%$ at the University of Linz, $12 \%$ at the University of Graz and the University of Innsbruck. During the 2011 winter semester, 1,750 doctoral students in the field of social (and economic) sciences were enrolled at the University of Vienna and 527 at the University of Graz. In the following sections, procedures and processes that regulate the academic lives of students enrolled as Doktorat Neu are described.

\section{Research Design}

Our two case studies are based on a mixed method approach including the triangulation of different sources of evidence (Yin, 2009). According to Flyvbjerg (2011), "case studies comprise more detail, richness, completeness, and variance - that is, depth - for the unit of study than does cross-unit analysis" (p. 301). Moreover, analyses are carried out in relation to the relevant environmental context. In order to portray in-depth insights of Austrian doctoral reforms, we have mined information from online documents of national legal

14 In Austria, the academic year is divided into two semesters - the summer and the winter semester. Each semester is four months in length.

15 According to the Communiqué of the Conference of European Ministers Responsible for Higher Education (2005 \#3), "we consider participants in third cycle programmes both as students and as early stage researchers” (p. 4).

16 Twelve percent are enrolled at the University of Innsbruck and 9\% the Vienna University of Technology. Source: uni:data statistics, the data warehouse of the Austrian Federal Minister for Science and Research http://eportal.bmbwk.gv.at/portal/page?_pageid=93,95229\&_ $\mathrm{dad}=$ portal\&_schema=PORTAL\&. 
regulations (e.g., UG, 2002), doctoral curricula in the field of social sciences at the University of Vienna and the University of Graz, and doctoral enrolment statistics. The latter were made available by the Austrian Federal Minister for Science and Research and by the interviewees. In addition, to gain further insights into current practices and procedures, semi-structured interviews were conducted with five key expert informants. Interviews at the University of Vienna were conducted face-to-face at the interviewees' workplace. At the University of Graz, telephone interviews with interviewees were carried out. The interviews, which on average lasted for one hour, were conducted in June 2012. In the following sections, we provide a synopsis of the implementation of the Doktorat Neu; first, at the University of Vienna, and second, at the University of Graz.

\section{Doctoral Study in the Social Sciences at the University of Vienna ${ }^{17}$}

Of all of the faculties at the University of Vienna and in Austria, the Faculty of Social Sciences at the University of Vienna enrols the second largest number of doctoral students. Admission to Doktorat Neu entails registration and payment of student union fees ("ÖH Beitrag"). Neither a designated supervisor nor the doctoral dissertation topic is required at this point. Individual doctoral study is divided into two parts. The first year is considered to be an entry and conception phase, followed by two years of research and completion of the doctoral dissertation. During the entry phase, each student must find a research supervisor, attend a maximum of 10-ECTS credits of course work, and write a research proposal. At the end of the first year, the doctoral student is expected to present her or his research proposal to the faculty. In order to facilitate the latter requirement, several doctoral advisory boards ${ }^{18}$ have been established at the institutional level. Members of doctoral advisory boards for Social Sciences evaluate the doctoral dissertation proposal of the prospective doctoral student. Following a positive assessment of the proposal, the doctoral student can then negotiate and sign a doctoral dissertation agreement. Only those who have received both a positive evaluation and have signed doctoral dissertation agreements in place are permitted to attend the additional courses required to

17 Figures and numbers have been made available by the Centre for Doctoral Studies at the University of Vienna.

18 In the Faculty of Social Sciences, six doctoral dissertation advisory boards with six or seven members have been established. Detailed information can be found at: http://doktorat.univie. ac.at/en/supervisors/doctoral-advisory-board/doctoral-advisory-board-for-the-director-of-thestudy-program-number-40-for-the-following-fields-of-doctoral-research. 
complete their doctorate (20-ECTS credits). The doctoral dissertation agreement between the student and supervisor specifies the tasks to be achieved within each year, such as papers to be written, courses to be completed, and poster conference presentations to be made. Annual reports provide insights into the prescribed and fulfilled tasks of the doctoral project. In this semi-structured Doktorat Neu programme, students must earn 30 ECTS credits overall. No further ECTS points are granted for the dissertation or defence.

In the summer semester 2012 in the Faculty of Social Sciences, 714 of 1,734 doctoral students ${ }^{19}$ were enrolled in the Doktorat Neu programme. Of the 221 new doctoral students or "early stage researchers" who started their doctoral studies in 2009, 110 were still actively enrolled in the summer of 2012 . The remaining 111 students had withdrawn. ${ }^{20}$ By March 2012, only 23 of the 110 doctoral students had received positive evaluations from doctoral advisory boards and had signed doctoral dissertation agreements. To date, 87 students have not yet signed doctoral dissertation agreements. Reasons for the lack of progress by $79 \%$ of the 2009 cohort remain unclear. Currently, the number of presentations a doctoral student can make is unrestricted. However, according to the interviewees, after having made one unsuccessful attempt, an unspecified number of students subsequently withdraw. Only a minority of doctoral students have presented their doctoral dissertation proposals two or three times.

It is noteworthy that in the Faculty of Social Sciences, the 110 active early stage researcher survivors of the winter semester 2009 have a pool of 50 supervisors with the status of either Professor or Habilitation. In other words, there is an average of two doctoral students per supervisor. At first blush, this appears to be a shift towards the realm of supervisory feasibility. In reality, however, 1,734 doctoral students are currently enrolled in the Faculty of Social Sciences, which is an untenable number of 35 students for every supervisor!

The intention of the restructuring process to assure the quality of doctoral studies and actual practice can be determined by examining both the intended and non-intended effects of the restructuring endeavour. Student presentations of proposed doctoral projects to faculty advisory boards were intended to ensure greater public visibility and to introduce a measure of quality assurance. The intended role of advisory boards was to offer practical recommendations, which would then be used to improve the doctoral dissertation proposal. Since there are no regulations in place regarding how often students can present, in theory each student has the opportunity to present until a positive review has been obtained. According to comments made by interviewees

19 The remaining 1,020 students are enrolled in the old doctoral programme.

20 Withdrawal requires no action on the part of the student. 
and supported by official statistics, some members of doctoral advisory boards use the doctoral proposal presentation as a screening mechanism. This hurdle in the doctoral programme provides an opportunity for faculty to reduce and regulate the number of students by weeding out poor performers. The doctoral proposal presentation also serves as a self-elimination mechanism, as many doctoral students do not attempt to re-present their proposals. Over one fifth (21\%) of enrolled doctoral students have passed the required courses and have written their proposals, but they are unable to find a supervisor. A doctoral proposal presentation is not permitted without an established supervisor. According to university regulations, in such cases of hardship, the Chair of the doctoral advisory board is required to assign a supervisor. To date, no instances of assigned supervision have been documented; however, an indeterminate number of cases are rumoured to exist.

Another element of quality assurance is the requirement of a doctoral dissertation agreement. This new procedure is intended to concretise commitments from both the doctoral student and the supervisor. The doctoral student is provided an opportunity to ensure that the tasks agreed upon in a given year are (1) related to her or his doctoral project, (2) are realistic, and (3) achievable. Likewise, it is a mechanism to formally specify the responsibilities of the supervisor. When compared to students enrolled under the old regime, where it was not uncommon to have not seen their supervisors for the majority of their doctoral studies, doctoral dissertation agreements also specify the number of supervisor consulting hours. Furthermore, newly offered courses with compulsory attendance provide additional opportunities for students and faculty to address, discuss and refine research-related questions.

Supervisors are no longer evaluators of the doctoral dissertation. According to university regulations, both evaluators should be external. Currently, the extent to which the evaluations are external remains ambiguous. As of June 2012, only three doctoral dissertations have been completed. Two were evaluated by their supervisors and one by an assessor external to the University of Vienna. As none of the students who were admitted to the Doktorat Neu programme have defended their dissertations, it is not possible to examine intended versus actual practices regarding dissertation evaluation.

\section{Doctoral Study in Social and Economic Sciences at the University of Graz}

Similar to the University of Vienna, at the University of Graz neither a designated supervisor nor an identified doctoral dissertation topic is required 
to enrol. Doctoral study at the Faculty of Social and Economic Sciences is highly modularised and fully structured. The programme has undergone two stages of reforms (2007 and 2009). In the second reform, examination procedures and policies were developed. The oral defence was split into two parts (Rigorosum 1 and Rigorosum 2), which is unique at the University of Graz.

After having enrolled as a doctoral student, several steps are required:

1. successful completion of mathematics and statistics courses and empirical methods in the social sciences for a total of 18 ECTS points;

2. submission of the doctoral dissertation proposal;

3. attendance at more detailed research methods in social sciences (18 ECTS);

4. successful completion of an oral mid-term defence based on completed coursework (Rigorosum 1);

5. participation at doctoral colloquia;

6. completion of the doctoral dissertation;

7. second oral defence of the doctoral dissertation project (Rigorosum 2).

The required coursework at the beginning of doctoral study was intended to expose all students to a common curriculum. In addition, requiring them to complete 48 ECTS points and the "Rigorosum 1" before they are allowed to proceed to the next steps was intended as a mechanism for selecting the most promising students. Data to date indicate that these requirements constitute a major obstacle for many early stage researchers. Instead of attending the examination, many simply do not continue with their studies. Students must complete a total of 60 ECTS points through coursework and oral defences of the research project.

At the University of Graz, a supervision agreement signed by the principal supervisor, the doctoral student and the co-supervisor is required. This contractual agreement specifies (1) the requirement that the student attends a minimum of two consultation appointments, (2) the target date for completing the doctoral dissertation, (3) modes of communication between the student and supervisors, and (4) planned presentations by the student. An annual written report is also required, and supervisors are encouraged to inform their students about conferences and to introduce them to scholarly networks and communities.

Although these agreements serve as an awareness raising mechanism for the supervisor by specifying her or his responsibilities, they cannot be considered to be a quality assurance tool for better supervision. Data documenting 
the number of signed agreements are not available, but such data collection endeavours are planned for the future.

Assessment of the doctoral dissertation is carried out primarily by qualified faculty from a different faculty or institution, but not by the supervisor. Although external assessors are recommended, they are not mandatory. Here, practice is linked to financial constraints, in that travel and subsistence expenses required for external assessors imposes a burden on the budget of the Faculty of Social and Economic Sciences.

In the Faculty of Social and Economic Sciences, the doctoral curriculum is highly modularised. Such modularisation in terms of structures and coursework has been strongly influenced by the Faculty's interpretation of the goals of the Bologna Process. Currently, the Faculty are considering reversing modularisation at the level of doctoral studies (third study cycle), with the goal of reducing the overall number of ECTS points required. The content of coursework has also been criticised. For example, some required courses do not fit the needs of the doctoral students studying sociology. The creation of a separate doctoral school of sociology is currently being entertained.

\section{Discussion}

Our analyses demonstrate that both the University of Vienna and the University of Graz have implemented reform steps that constitute a departure from the traditional apprenticeship model of doctoral education. However, both universities have a considerably long way to go if the intention is to fully implement a professional model. Briefly, we highlight the achievements and shortcomings of the reform by referring to the five questions that we posed earlier in this paper.

Regarding admission procedures, Austrian universities continue to be forced to live with the idiosyncratic "no admission" policy that is codified in the University Act 2002. However, they increasingly find ways to circumvent this policy by establishing internal overt and covert screening mechanisms. As a consequence, huge numbers of students enrol, only to be frustrated by unsuccessful attempts to have their research proposals accepted and to find a supervisor. In many ways, the traditional pattern is maintained; however, these prerequisites constitute a visible signal to students and faculty, and make the distinction between paper students and students who effectively work on their dissertation much more transparent than before.

In terms of implementing the Doktorat $\mathrm{Neu}$, there are similarities and differences at the two universities. Both universities have increasingly emphasised 
the role of the institution in doctoral education. At the University of Vienna, the role of the institution, as opposed to that of the individual supervisor, has been strengthened by the introduction of faculty advisory boards. These boards determine whether doctoral students are allowed to remain in the programme. As a consequence, the traditional notion of the sole responsibility of the professor has given way, somewhat, to regulations, policies and procedures at the faculty level that limit the discretion of the individual supervisor and increasingly standardise the doctoral experience. Formal criteria for decision-making processes are not well defined, however, and remain as one key task to be resolved. At the University of Graz, the main focus of reform has been the introduction of extensive coursework and two oral examinations to which retention in the programme is linked. Both universities have implemented a supervision contract that is intended to clarify expectations among the student, the supervisor and other committee members. This process of standardisation is accompanied by various forms of shared responsibility within the faculty and departments, at least in the early stages of doctoral education. Once students start to work on their dissertations, it appears that individual supervisors continue to have the upper hand regarding the research that is carried out by the student.

In terms of curricular differences, both universities have introduced mandatory coursework to increase the rigour of students' programmes of study, to promote regular engagement with faculty, and to provide students with the knowledge base and skills to complete their dissertations. However, because students' research interests are not vetted at the time of enrolment to ensure that they are in line with faculty members' interests and areas of expertise, it is a Herculean challenge to design courses that suit the needs of all students.

With respect to assessment, each university has taken a different approach. At the University of Vienna, the social sciences have followed the sciences by adopting the professional practice of external assessment. At the University of Graz, assessment by supervisors prevails.

As our findings for the University of Vienna demonstrate, to date the reforms have had an impact on enrolment numbers. Measures that have been introduced to increase the rigour of doctoral studies have resulted in reducing the proportion of students who remain in the programme. At the University of Graz, demanding coursework and the mid-term oral examination serve to weed out the less capable, the less persistent, or both.

To conclude, reform of doctoral education is a far-reaching process that is as profound as the introduction of the new Bachelor's degree. It is likely that the recently created and adopted regulations described in our case studies are intermediate stopgap measures that will continue to evolve through a process of 
trial and error. A considerable amount of time and experience will be necessary before a stable system of doctoral study procedures emerges. To fully enact a professional model of doctoral education, faculties of postgraduate studies that develop regulations and policies for the entire postgraduate student population will probably be required. Furthermore, North American sensibilities regarding student services and support would enhance the doctoral experience for students. Nonetheless, the magnitude of change in a relatively short time is impressive.

\section{Reference}

Anderson, R. D. (2004). European universities from the enlightenment to 1914. Oxford: Oxford University Press.

Clark, W. (2006). Academic charisma and the origins of the research university. Chicago: The University of Chicago Press.

Esping-Andersen, G. (1990). The three worlds of welfare capitalism Princeton: Princeton University Press.

European Ministers Responsible for Higher Education. (2005). The European Higher Education Area - Achieving the goals. Bergen: Communiqué of the Conference of European Ministers Responsible for Higher Education, May 19-20.

Ferz, S. (2000). Ewige Universitätsreform. Das Organisationsrecht der österreichischen Universitäten von den theresianischen Reformen bis zum UOG 1993. Frankfurt Main: Peter Lang.

Flyvbjerg, B. (2011). Case study. In N. K. Denzin, \& Y. S. Lincoln (Eds.), The Sage handbook of qualitative research (pp. 301-316). Thousand Oaks, CA: Sage.

Gade, M. L. (Ed.) (1991). International Higher Education. An Encyclopedia. Chicago/London: St. James Press.

Götz, E. (1993). Chronologie der Studienreform 1962-1966. In: BMWF (Ed.), Materialien zur Studienreform. Wien: BMWF.

Graf, L., Lassnigg, L., \& Powell, J. J. W. (2012). Austrian corporatism and institutional change in the relationship between apprenticeship training and school-based VET. In M. R. Busemeyer, \& C. Trampusch (Eds.), The political economy of collective skill formation (pp. 150-178). Oxford: Oxford University Press.

Novak, M. (Ed.) (2006). Handbuch des österreichischen Hochschulrechts. Graz: nwv Verlag. OECD. (2007). Education at a glance. OECD indicators 2007. Paris: OECD.

OECD. (2011). Education at a glance. OECD indicators 2011. Paris: OECD.

Paletschek, S. (1998). Wie die Forschung in die Lehre kam. attempto! Forum der Universität Tübingen, 4, 34-35.

Pechar, H. (2005). Backlash or modernisation? Two reform cycles in Austrian higher education. In A. Amaral, M. Kogan, \& A. Gornitzka (Eds.), Reform and change in higher education. Analysing policy 
implementations (pp. 269-285). Dordrecht: Springer.

Pechar, H. (2009). Can research universities survive without control over admission? Reflections on Austria’s exceptionalism in higher education policy. Journal of Adult \& Continuing Education, 15(2), 142-154.

Pechar, H. (2012). The decline of an academic oligarchy. The Bologna Process and 'Humboldt's last warriors.' In A. Curaj, P. Scott, L. Vlasceanu, \& L. Wilson (Eds.), European higher education at the crossroads: Between the Bologna Process and national reforms (pp. 613-630). Dordrecht Springer. Pechar, H., \& Andres, L. (2011). Higher education policies and welfare regimes: International comparative perspectives. Higher Education Policy, 24, 25-52.

Rasche, U. (2007a). Die deutschen Universitäten und die ständische Gesellschaft. In R. A. Müller (Ed.), Bilder - Daten - Promotionen. Studien zum Promotionswesen an deutschen Universitä ten der frühen Neuzeit (pp. 150-273). Stuttgart: Franz Steiner Verlag.

Rasche, U. (2007b). Geschichte der Promotion in absentia. Eine Studie zum Modernisierungsprozess der deutschen Universitäten im 18. und 19. Jahrhundert. In R. C. Schwinges (Ed.), Examen, Titel, Promotionen. Akademisches und staatliches Qualifikationswesen vom 13. bis zum 21. Jahrhundert (pp. 275-351). Basel: Schwabe.

Realising the European higher education area. (2003). Berlin: Communiqué of the Conference of Ministers resonsible for Higher Education. September 19.

Rhoades, G. (1991). Graduate education. In P. Altbach (Ed.), International Higher Education. An Encyclopedia (pp. 127-146). Chicago/London: St. James Press.

Schibany, A., Berger, M., Dachs, B., Dinges, M., Gassler, H., Janger, J., et al. (2011). Austrian research and technology report 2011. Vienna: Federal Ministry of Science and Research (BMWF).

Turner, R. (1960). Sponsored and contest mobility and the school system. American Sociological Review, 25(6), 855-867.

Yin, R. K. (2009). Case study research. Design and methods. Beverly Hills: Sage. 


\section{Biographical note}

Hans Pechar is a Professor of higher education at Alpen-Adria University, Vienna, location. The focus of his research is comparative higher education and economics of higher education. He is a member of the Board of Governors of the German speaking Society of Research in Higher Education and represents Austria in the governing board of OECD CERI. Most recently, his publications have addressed topics of policies of access to higher education, governance of Austrian universities, and equity in education.

GüLAY ATES studied sociology and educational studies in Heidelberg and graduated from the University at Vienna in sociology. Currently she is a $\mathrm{PhD}$ student at Alpen-Adria University and a lecturer at the University of Vienna, specialising in Higher Education, Migration, and Integration Research. Her PhD thesis focuses on the reform of doctoral studies in Austria. She is a member of the Eurodoc survey experts team and president of doktorat.at, an Austrian association of early career researchers.

LeSley ANDRes is a Professor in the Department of Educational Studies at the University of British Columbia. She is the principal investigator of the Paths on Life's Way Project, a unique Canadian longitudinal study that has combined extensive qualitative and quantitative data over a 22 year time frame to examine the lives, actions, experiences, and perspectives of individuals within a life course framework. Her most recent books are Designing and Doing Survey Research (2012) and The Making of a Generation: Children of the 1970s in Adulthood (2010, co-authored with Johanna Wyn). Also, she is the Editor-inChief of the Canadian Journal of Higher Education. 